\title{
A Study of the Influence of Social Ideological Trends on College Students' Ideological Quality*
}

\author{
$\mathrm{Na} \mathrm{An}$ \\ School of Marxism \\ School of Economics and Management \\ Beijing Jiaotong University \\ Beijing, China 100044
}

\begin{abstract}
In recent years, social ideological trends have shown sporadic and fragmentary, perceptual and daily life, mutual penetration and mutual development. The social ideological trends have had a double influence on the development of college students' ideological quality. In view of the negative influence of social ideological trends on the development of college students' ideological qualities, strengthening the education of Marxist theory, nurturing positive energy flag bearer of social ideological trends, strengthening the construction of campus culture, and deepening the research and judgment of social ideological trends are the main countermeasures.
\end{abstract}

Keywords-social ideological trends; college students' ideological quality; ideological and political education

\section{INTRODUCTION}

With the deepening of globalization and China's reform and opening up, Western social ideological trends have flooded into China and they have had fierce confrontation and integration with domestic social ideological trends [1]. College students are in the period of formation and development of world outlook, outlook on life, and values, and are easily influenced by social ideological trends. Focusing on the growth needs of college students, understanding their ideological trends and changes in their value orientation, and guiding their rational treatment of social ideological trends have become an important part of ideological and political education in universities.

\section{THE DEVELOPING CONDITION OF SOCIAL IDEOLOGICAL TRENDS}

In recent years, the development of social ideological trends has shown some new changes, mainly in the following areas:

\section{A. Sporadic and Fragmented Development Condition}

In the 1980s, social ideological trends mainly affected the students of universities with the correctness of the theory and the integrity of the viewpoint [2]. Various social ideological

*Fund Project: The humanities and Social Sciences projects of the Ministry of education of China "Research on the Spread Mechanism and Leading of Social Trend of Thought in the New Media Age" (Grant No.17YJC710001) trends were also propagated mainly in the form of theory. However, due to the in-depth development of the market economy, college students have changed their acceptance of social ideological trends. Although college students are still very concerned about the theoretical significance of social ideological trends in solving social problems, those social ideological trends that contain novelty, usefulness, comprehension, and popularity easy to accept by college students. The reason why college students accept social ideological trends is not because of the correctness, systematicness, and theoretical integrity of their viewpoints, but also to accept social ideological trends in a perceptual manner, which makes social ideological trends appear sporadic and fragmented.

\section{B. Perceptual and Living Development Condition}

Relevant investigations have shown that newspapers, magazines, books and classroom teaching are still the basic ways for college students to understand social ideological trends. However, the ways in which college students understand social ideological trends are diversified. If we further differentiate students' understanding channels of social ideological, classroom teaching and academic lectures should be regarded as channels for understanding social trends in the classroom; extracurricular activities, academic conferences, classmates, friends, parents, teachers, newspapers, books, films, television, and the Internet are viewed as channels for understanding social ideological trends outside of class; classroom teaching, academic lectures, academic conferences, newspapers and magazines, etc. can be viewed as academic or rational ways to obtain social ideological information; extracurricular activities, classmates, friends, parents, teachers , Internet, film and television, and cultural entertainment are viewed as acquiring social ideological information through activities or perceptual means. Then we will find that the impact of social ideological trends on the development of the ideological quality of college students is taken in an extra-curricular manner and through perceptual and life channels.

\section{Mutual Infiltration and Mutual Development Condition}

Among contemporary college students, most students do not have a clear line of thought on neo-liberalism, historical nihilism, cultural conservatism, and public intellectuals. To a 
certain extent, they more often think of these thoughts as something of the same ideological foundation and content, and even confuse various thoughts with each other. On the one hand, it shows that contemporary college students do not only accept social ideological trends through an in-depth understanding of a social ideological trend; on the other hand, it shows that various social ideological trends are not transmitted in a single way.

\section{THE Positive INFLUENCE OF SOCIAL IDEOLOGICAL}

\section{TRENDS ON COLLEGE STUDENTS' IDEOLOGICAL QUALITY}

The positive impact mainly includes the following aspects:

\section{A. It Has Promoted Some College Students to Broaden Their Horizons and Satisfy Their Desire for Knowledge}

There are many different classifications of contemporary social ideological trends from different standards. Among various social ideological trends, there are social ideological trends that examine the current situation of human society and predict the future human social development from a macro perspective. There are also social ideological trends that focus on the effectiveness and obstacles of social, political, economic, and cultural reforms from a micro perspective. The rich variety of social ideological trends involving a wide range of fields can provide college students with adequate cultural knowledge, and have a positive effect on their understanding of the world, cognizing of society, and the acquisition of various cultural achievements.

\section{B. It Has Promoted Some College Students to Enhance Their Critical Awareness and Promote Their Individual Development}

Various problems in social development emerge in an endless stream. Social ideological trends try to analyze social issues from different perspectives, resulting in diversified styles and multiple perspectives. College students are full of enthusiasm and critical spirit. They often express their thoughts through various channels such as online forums, Weibo, and WeChat on issues of concern to them, such as ecological issues, human rights issues, and globalization issues that are of common concern to the international community. This is the process in which they fully exert their subjective initiative, continuously strengthen their critical awareness, then distinguish and think different social ideological trends in absorbing social ideological trends. Therefore, with regard to major social issues such as corruption, employment difficulties and moral decline, contemporary college students can make their own unique insights after proceeding with rational considerations based on China's specific national conditions and reality.

\section{ThE NEGATIVE INFLUENCE OF SOCIAL TREND OF} THOUGHT ON COLLEGE STUDENTS' IDEOLOGICAL QUALITY

The negative effects mainly include the following aspects:

\section{A. It Has Caused Some College Students to Have a Belief Crisis and Weaken Their Political Identity}

Because of the lack of ability to analyze social issues in depth, college students cannot fully understand the difficulties and challenges that our country may face in socialist modernization. When they come into contact with "new ideas" of neo-liberalism, historical nihilism, universal value on books and on the Internet, they will be immediately attracted and mistakenly believed that the theory and viewpoints of these social ideological trends are correct. Under the influence of these erroneous social ideological trends, a small number of undergraduates showed skepticism and belief crisis in Marxism and Chinese-style socialism. They believe that Marxism is "useless" and "out of date". They even doubt the superiority of the path of socialism with Chinese characteristics and believe that communism cannot be achieved, thus giving up the exploration of the world and the pursuit of socialism with Chinese characteristics.

\section{B. It Has Caused Some College Students to Lack of Social Responsibility and Social Morality}

At present, under the influence of the neo-liberal social ideological trends, some undergraduates are bewildered by the superficial material phenomena of western capitalist countries, evoking them to produce such favors as money worship, hedonism, and individualism. A small number of college students are pursuing material money and sensual enjoyment. They gradually give up their responsibilities to the society and others, give up moral principles and sincere principles, and use these bad social thoughts as their own philosophy of life. Specifically, they show no concern for other people's affairs, have no enthusiasm for the affairs of the class, and never participate in school activities. In addition to their own things, they are not interested in anything. These students rarely participate in volunteer activities, despise social contributions, and are unwilling to pay for others.

\section{It Has Induced Some College Students to Develop Idealistic Cultural Views and a Narrow-minded Cultural Mentality}

Cultural conservatives advocate the idealist view of cultural history and believe that Confucian culture plays a guiding and decisive role in the development of human society. It should be said that the national wisdom and traditional virtues of Confucian culture accumulated in the historical heritage have extremely high value, but the Confucian culture has lost its original value as an agricultural social culture. The cultural conservatives ignore these realities and strongly exaggerate the decisive role of Confucian culture, and use Confucian culture as the yardstick for tailoring Chinese history and determining the country's direction. This point of view can easily lead to college students showing a radical, paranoid cultural mentality. 


\section{The WAY To DEAL WiTH THE NEGATIVE INFLUENCE OF SOCIAL IDEOLOGICAL TRENDS ON COLLEGE STUDENTS' IDEOLOGICAL QUALITY}

In response to the negative influence of social ideological trends on college students' ideological qualities, the response path includes the following aspects:

\section{A. We Must Strengthen Marxist Theory Education}

The emergence and development of Marxism is the result of the constant struggle between it and the pluralistic social ideological trends. In the ideological field, we must unswervingly adhere to the basic principles and important status of Marxism in all circumstances, and firmly hold the prevailing thought in the consciousness field of our country in order to improve our ability to control and lead the social ideological trends. The theory, nature, and viewpoints of social thought are mixed. If college students want to correctly understand and identify the essence of social ideological trends, they must use Marxist basic theories as ideological weapons. This requires that Marxist theory education must be used as the soul of college students' ideological and political education, guide college students to seriously read Marx's original works and translations, conscientiously study and understand, and establish Marxist positions, viewpoints, and methods [3]. At the same time, it is necessary to continuously upgrade the theoretical qualities of college students, promote their socialist convictions and communist ideals, and constantly enhance their skills in resisting various risks and discerning the essence of various social ideological trends, and actively oppose all negative social ideological trends.

\section{B. We Should Nurture Positive Energy Flag Bearer of Social Ideological Trends}

In order to improve the effectiveness of ideological and political education for college students and actively respond to the impact of social ideological trends on college students, the key lies in the ideological and political education workforce. Raising the theoretical and practical level of the ideological and political work team in an all-round way and cultivating positive energy flag bearer of social ideological trends are the fundamental guarantee for achieving effective leadership of social ideological trends and eliminating its negative impact on university students. The backbone of college students' ideological and political education work team includes party and government personnel, leading cadres, and teachers (especially teachers of humanities and social sciences), as well as counselors and headteachers who have more contact with students [4]. The ideological and political education work teams must work together to make concerted efforts and cooperate with each other to form a joint force. For this reason, the ideological and political education work team in colleges must not only master the principles of Marxism, but also master the theoretical results of Marxism that is advancing with the times, that is, theory of socialism with Chinese characteristics. At the same time, we must always pay attention to the development of social ideological trends and their impact on university students. We can be sensitive to capture the hotspots, focus, and doubts of college students' thoughts caused by the spread of social ideological trends, and can conduct scientific and persuasive analysis based on the principles of Marxism. In this way, it will help improve college students' political identification ability and scientific analysis to social ideological trends.

\section{We Must Strengthen the Construction of Campus Culture}

College campuses are the main venue for cultivating talents, and they are also the main positions for cultivating students' mainstream ideology. Campus culture is a reflection of the school's philosophy and spirit. A civilized and harmonious campus culture can have a positive impact on the formation of college students' correct values and the development of their physical and mental health. To strengthen the construction of campus culture, we must do the following. First of all, colleges and universities must always adhere to the goal of educating people, enrich campus cultural life, and actively create a campus culture atmosphere centered on propaganda, collectivism, patriotism, and Marxist ideology. In this way, students in all kinds of complex social ideological trends can understand the main theme and consciously resist the erosion of bad social ideological trends. Secondly, colleges and universities must continue to innovate the management mechanism of campus culture, strengthen the guidance of cultural activities, improve the layout of learning sites, and create a positive cultural atmosphere, so that the construction of campus culture can be effectively integrated into school education and daily management. Again, we must pay attention to the construction of the school's appearance and continuously strengthen the beautification of the campus environment. In this way, students are encouraged to receive scientific and modern information in a harmonious campus culture environment.

\section{We Must Deepen Our Judgment on Social Ideological Trends}

In order to exert political influence, the current social ideological trends often express their political ideas in either academic or ideological or public or covert forms. Their inherent nature is often covered by superficial phenomena or numerous illusions. This requires that we must use Marxist perspectives to study the historical context of social ideological trends, analyze their theoretical systems and political appeals, and reveal their basic characteristics and intrinsic nature. For the correct social ideological trends, we must actively guide them to continue to develop in the right direction. For the erroneous social ideological trends that seriously challenge mainstream ideology and seriously interfere with China's main theme, we must sharply criticize and dialysis and must not let it go. At the same time, we must focus on the hot issues and guard against the evolution of erroneous social ideological trends among young students. In view of the problems that may arise, it is necessary to conduct research in advance and take the initiative to do a good job of public opinion guidance and trend monitoring to prevent college students from having confusion in their thinking. 


\section{CONCLUSION}

Contemporary social ideological trends are turbulent, complex and changeable. They have different levels of influence on the ideological quality of college students. Under the new situation, we must adhere to the guiding position of Marxism, firmly grasp the leadership and discourse power of ideological work in colleges and universities, and constantly improve the ideological quality of college students. Only in this way can the young university students continuously strengthen their ability to resist various risks and correctly identify the essence of various social ideological trends in the face of the everchanging social situation.

\section{REFERENCES}

[1] L. Wei, "On Deepening the Scientific Research of Social Control", Theory Journal, vol. 2, pp. 140-140, 2017.

[2] N. An, J.C. Lin. "The Propagation Characteristics and Guidance of Social Thought in New Media", socialism studies, vol. 6, pp. 119-119, 2016.

[3] L. Wei, "Giving full play to the leading role of the Chinese Communist Party in social control", theoretical investigation, vol. 5, pp. 127-127, 2013.

[4] Y.Y. Li, The Socialist Core Value System Leads the Ideological Trend of University Students, CN: People's Publishing House, pp. $157-158,2015$. 